\section{Morphological and Physiological Responses of Nine Ornamental Species to Saline Irrigation Water}

\author{
Shasha Wu \\ College of Landscape Architecture, Fujian Agriculture and Forestry \\ University, No. 15 Shangxiadian Road, Cangshan District, Fuzhou, Fujian \\ 350002, China; and Texas A\&M AgriLife Research Center at El Paso, Texas \\ A\&M University System, 1380 A\&M Circle, El Paso, TX 79927
}

\author{
Youping Sun ${ }^{1}$ and Genhua Niu ${ }^{1}$ \\ Texas A\&M AgriLife Research Center at El Paso, Texas A\&M University \\ System, 1380 A\&M Circle, El Paso, TX 79927
}

\section{Additional index words. landscape irrigation, salt foliar damage, salt tolerance}

\begin{abstract}
To provide more species for landscapes where poor-quality irrigation water is used, salt tolerance of commonly used landscape plants should be characterized. Nine ornamental species, including six herbaceous and three woody, were irrigated with nutrient solution at electrical conductivity (EC) of $1.2 \mathrm{dS} \cdot \mathrm{m}^{-1}$ (control) or saline solution at EC of 5.0 or $10.0 \mathrm{dS} \cdot \mathrm{m}^{-1}$ (EC 5 or EC 10) for 8 weeks and their growth and physiological responses were determined. Although growth was reduced in orange peel jessamine (Cestrum 'Orange Peel') and mexican hummingbird bush (Dicliptera suberecta) as salinity increased, no obvious signs of stress or injury were observed, indicating that orange peel jessamine and mexican hummingbird bush were the most salt tolerant. Flame acanthus (Anisacanthus quadrifidus var. wrightii), rock rose (Pavonia lasiopetala), and 'Dark knight' bluebeard (Caryopteris $\times$ clandonensis 'Dark Knight') had more growth reduction than that of orange peel jessamine and mexican hummingbird bush with minimal or no foliar damage in EC 5 and slight foliar damage in EC 10. Cardinal flower (Lobelia cardinalis) and mexican false heather (Cuphea hyssopifolia) exhibited mortality rates of $30 \%$ and $20 \%$, severe foliar damage, and greater than $70 \%$ reduction in leaf area and dry weight in EC 10 compared with their respective controls. Although the growth reductions in butterfly blue (Scabiosa columbaria) were not as great as cardinal flower and mexican false heather, $40 \%$ of butterfly blue plants were dead with moderate foliar damage in EC 10. Therefore, cardinal flower, mexican false heather, and butterfly blue plants were considered as moderately salt sensitive. Eastern red columbine (Aquilegia canadensis) was the most salt sensitive among the species investigated with moderate foliar damage in EC 5 and all plants died in EC 10. Four out of the nine species tested had significant differences in net photosynthetic rate $\left(P_{n}\right)$, stomatal conductance $\left(g_{s}\right)$, and/or relative chlorophyll content between the control and EC 10 , and the difference varied with species. Shoot ion concentrations of the nine ornamentals were also affected by salinity levels and varied among species.
\end{abstract}

Water quantity and quality are increasingly becoming critical global issues, especially in arid and semiarid regions, as well as in some coastal regions (Niu et al., 2012a). As municipalities are struggling to meet the demand for high-quality water to supply the

\footnotetext{
Received for publication 20 Nov. 2015. Accepted for publication $3 \mathrm{Feb} .2016$.

This research is supported by Specific Cooperative Agreement from Department of Agriculture (USDA), Agricultural Research Service, the USDA National Institute of Food and Agriculture Hatch project TEX090450, and Texas A\&M AgriLife Research

The contents are solely the responsibility of the authors and do not necessarily represent the official views of the funding agencies.

Shasha Wu was a visiting scholar at Texas A\&M AgriLife Research Center at El Paso financed by China Scholarship Council (CSC), China.

${ }^{1}$ Corresponding author. E-mail: Youping.sun@ ag.tamu.edu or gniu@ag.tamu.edu.
}

growing urban population, treated effluent (reclaimed water or recycled water) is an alternative water source for irrigating urban landscapes and agricultural and nursery crops in suburban areas (Niu and Rodriguez, 2006a). Many places have switched to use reclaimed water for irrigating landscapes and golf courses, such as many cities in California (San Diego County Water Authority, 2015; Wu and Dodge, 2005) and in Israel (Shillo et al., 2002). However, high salinity levels of recycled water may cause damage or even death to sensitive plants if not managed properly (Niu et al., 2012b)

Salinity can reduce growth and cause foliar salt damage through physiological drought, ion toxicity, and nutrient deficiency (Munns, 2002; Niu and Cabrera, 2010; Veatch-Blohm et al., 2014). Most landscape plant species are nonhalophytes; therefore, assessment of salt tolerance is necessary for landscapes where poor-quality water may be used for irrigation. The salt tolerance of landscape plants should be based primarily on aesthetic appearance rather than maximizing growth rate (Niu and Cabrera, 2010; Shillo et al., 2002; Veatch-Blohm et al., 2014). In the past decades, many landscape plants have been investigated for salt tolerance. For example, salt tolerance of 86 tree and palm species, 65 shrub species, 58 groundcover and vine species, and 57 grass species has been screened by $\mathrm{Wu}$ and Dodge (2005). The salt tolerance of more than 100 species/cultivars of herbaceous landscape plants has been determined by Niu group since 2006 (Niu and Rodriguez, 2006a, 2006b; Niu et al., 2007, 2010, 2012a, $2012 \mathrm{~b}$ ). Considering the huge number of plant species potentially available for landscapes, there are still thousands of plant species and cultivars that have not been investigated for salt tolerance. The objectives of this study were to compare the relative salt tolerance of nine ornamental species, which are widely used in landscapes, based on their visual quality, growth, number of flowers, gas exchange, chlorophyll content, and shoot ion concentration when irrigated with saline solution in a range of salinities.

\section{Materials and Methods}

Plant materials and growing conditions. Rooted cuttings in plugs trays of three widely used herbaceous ornamental plants: butterfly blue ( $S$. columbaria 'Butterfly Blue'), cardinal flower (L. cardinalis), and eastern red columbine (A. canadensis), three shrub-like perennials: mexican false heather $(C$. hyssopifolia), mexican hummingbird bush (D. suberecta), and rock rose ( $P$. lasiopetala), and three shrub species: 'Dark knight' bluebeard (Caryopteris $\times$ clandonensis 'Dark Knight'), flame acanthus (Anisacanthus quadrifidus var. wrightii), and orange peel jessamine (Cestrum 'Orange Peel') were received from Southwest Perennials (Dallas, TX) on 9 Apr. 2015. Uniform plants were selected and transplanted into 3.8-L pots with Metro-Mix 360 (SunGro Hort., Bellevue, WA) 1 week later. Until the initiation of treatments, all plants were well irrigated with a nutrient solution, which was made by adding $1 \mathrm{~g} \cdot \mathrm{L}^{-1} 15 \mathrm{~N}-2.2 \mathrm{P}-12.5 \mathrm{~K}$ (Peters 15-5-15 Ca-Mg Special; Scotts, Marysville, $\mathrm{OH})$ to reverse osmosis water. Two weeks after transplanting, plants were treated with nutrient $\left(\mathrm{EC}=1.2 \mathrm{dS} \cdot \mathrm{m}^{-1}\right.$, control) and saline solutions [EC of 5.0 $\mathrm{dS} \cdot \mathrm{m}^{-1}$ (EC 5) and $10.0 \mathrm{dS} \cdot \mathrm{m}^{-1}$ (EC 10)]. The average air temperature in the greenhouse was $27.4{ }^{\circ} \mathrm{C}$ day $/ 23.0{ }^{\circ} \mathrm{C}$ night. The average daily light integral of ambient light was $12.5 \mathrm{~mol} \cdot \mathrm{m}^{-2} \cdot \mathrm{d}^{-1}$ and the average relative humidity was $35.4 \%$ during the experiment period.

Saline solution treatments. There was a control and two salinity treatments with 10 plants per species per treatment. Saline solution at EC of $5.0 \mathrm{dS} \cdot \mathrm{m}^{-1}$ was prepared by adding $1.20 \mathrm{~g} \cdot \mathrm{L}^{-1}$ sodium chloride $(\mathrm{NaCl})$ and $1.16 \mathrm{~g} \cdot \mathrm{L}^{-1}$ calcium chloride $\left(\mathrm{CaCl}_{2}\right)$ to the nutrient solution mentioned above, and $2.80 \mathrm{~g} \cdot \mathrm{L}^{-1} \mathrm{NaCl}$ and $2.67 \mathrm{~g} \cdot \mathrm{L}^{-1} \mathrm{CaCl}_{2}$ were added for $\mathrm{EC}$ of $10.0 \mathrm{dS} \cdot \mathrm{m}^{-1}$. Saline solutions 
were prepared in 100-L tanks with confirmed EC levels for each treatment using an EC meter (Model B173; Horiba, Ltd., Kyoto, Japan) before irrigation. Plants were irrigated with treatment solution weekly from 1 May to 19 June (eight times in total), instead of at every irrigation to avoid rapid salt accumulation in the substrate. Between the treatment solution irrigations, plants were irrigated with nutrient solution as needed. From 22 to 25 June, all plants were watered with nutrient solution until harvest. Plants were irrigated with $1 \mathrm{~L}$ solution per pot, which resulted in an $\approx 21 \%$ leaching fraction.

Leachate EC, substrate EC, and survival percentage. The leachate ECs were determined according to the pour-through methods (Cavins et al., 2008) on three plants per species each time after saline solution treatment. The substrate final ECs of each treatment were determined using saturated paste extract (Gavlak et al., 1994) on three plants per species per treatment 1 week after harvest. The number of dead plants was recorded before harvest, and survival percentage was calculated.

Foliar salt damage evaluation. Foliar salt damage, such as leaf edge burn, necrosis, and discoloration, of each plant was determined at the end of the experiment by giving a visual score based on a criterion reference scale from 0 to 5 , where $0=$ dead, $1=$ over $90 \%$ foliar damage, $2=$ moderate $(50 \%$ to $90 \%)$ foliar damage, $3=$ slight (less than $50 \%$ ) foliar damage, $4=$ good quality with minimal foliar damage, and $5=$ excellent with no foliar damage.

Growth parameters. Plant height, from the joint of stem and root to the top of shoot (usually to the tallest flower), was recorded at the end of the experiment. In eastern red columbine, cardinal flower, and butterfly blue, growth index (average of height and two crown diameters at perpendicular directions) were used because of their spheroidal shape, whereas plant height was applied for the other six species. The shoots of all plants were severed at the substrate surface at harvest. Leaf area of all living plants was determined using LI-3100C area meter (LI-COR ${ }^{\circledR}$ Biosciences, Lincoln, NE). Number of inflorescences was counted, regardless of whether they were flower buds, open flowers, or faded flowers. Thereafter, aboveground parts (including stems, leaves, and flowers) were harvested and dry weight (DW) was determined after oven-drying at $70^{\circ} \mathrm{C}$ for $4 \mathrm{~d}$.

Gas exchange. Leaf $\mathrm{P}_{\mathrm{n}}$, transpiration (E), and $g_{\mathrm{S}}$ of four plants per species per treatment were measured at the end of the experiment (18 June) using a CIRAS-2 portable photosynthesis system (PP Systems, Amesbury, MA) with an automatic universal PLC6 broad leaf cuvette. The fully expanded leaf at the top of the plant was chosen for the measurements. The environmental conditions within the cuvette were maintained at leaf temperature of $25{ }^{\circ} \mathrm{C}$, photosynthetic photon flux of $1000 \mu \mathrm{mol} \cdot \mathrm{m}^{-2} \cdot \mathrm{s}^{-1}$, and $\mathrm{CO}_{2}$ concentration of $375 \mu \mathrm{mol} \cdot \mathrm{mol}^{-1}$. Data were recorded when the environmental conditions and gas exchange parameters in the cuvette became stable. These measurements were taken on a sunny day between 1000 and $1400 \mathrm{HR}$, and plants were well watered in the early morning to avoid water stress.

Leaf greenness. Leaf greenness (or relative chlorophyll content) was measured on six leaves per plant at similar middle positions of shoots for all living plants in each treatment using a portable chlorophyll meter (measured as the optical density, SPAD reading; Minolta Camera Co., Osaka, Japan) at the end of the experiment (19 June).

Chlorophyll fluorescence. Chlorophyll fluorescence was measured at 1000 and $1400 \mathrm{HR}$ on 19 June using a pocket PEA chlorophyll fluorimeter (Hansatech Instruments Ltd., Norfolk, UK). Healthy and fully expanded leaves were chosen for the measurements. The leaves were dark adapted for at least $30 \mathrm{~min}$ before the measurements. Minimal fluorescence values in the darkadapted state $\left(\mathrm{F}_{0}\right)$ were obtained by application of a low-intensity red measuring light source $(627 \mathrm{~nm})$, whereas maximal fluorescence values $\left(\mathrm{F}_{\mathrm{m}}\right)$ were measured after applying a saturating light pulse of $3500 \mu \mathrm{mol}^{-2} \cdot \mathrm{m}^{-2} \cdot \mathrm{s}^{-1}$, and maximum quantum use efficiency of PSII in the dark-adapted state was calculated as $\mathrm{F}_{\mathrm{v}} / \mathrm{F}_{\mathrm{m}}=\left(\mathrm{F}_{\mathrm{m}}-\mathrm{F}_{0}\right) / \mathrm{F}_{\mathrm{m}}$.

Mineral analysis. Four samples per treatment per species were randomly selected from the ten samples for shoot mineral analysis. Dead plants of eastern red columbine in EC 10 were used since all plants died before the study ended. Dried shoots were ground to pass a 40-mesh screen with a stainless Wiley mill (Thomas Scientific, Swedesboro, NJ). Dried tissue samples were extracted with $2 \%$ acetic acid (EM Science, Gibbstown, HJ) for determining chloride $(\mathrm{Cl})$ using the method described in Gavlak et al. (1994). The concentration of $\mathrm{Cl}$ was determined by M926 Chloride Analyzer (Cole Parmer Instrument Company, Vernon Hills, IL). Dried tissue samples were submitted to the Soil, Water and Forage Testing Laboratory at Texas
A\&M University (College Station, TX) for determining alkaline earth metals $(\mathrm{Na}, \mathrm{K}$, and $\mathrm{Ca}$ ). In brief, plant powder samples were digested in nitric acid following the protocol described by Havlin and Soltanpour (1989). $\mathrm{Na}, \mathrm{K}$, and $\mathrm{Ca}$ in digested samples were analyzed by inductively coupled plasmaoptical emission spectrometry (SPECTRO Analytical Instruments Inc., Mahwah, NJ) and reported on a dry plant basis as described by Isaac and Johnson (1975).

Experimental design and statistical analysis. The experiment used a split-plot design with the salinity treatment as the main plot and nine species as the subplot with 10 replications per treatment for each species. Because of the difference in growth habits, a one-way analysis of variance was performed separately for each species for all data. Tukey's honest significant difference multiple comparisons were conducted among treatments within species. For eastern red columbine, data in EC 10 were excluded from analysis because of plant death, and Student's $t$ test was conducted to compare means of control and EC 5. Correlation analysis between leaf mineral concentration and visual quality was conducted. All statistical analyses were performed using JMP (Version 12; SAS Institute Inc., Cary, NC).

\section{Results}

Leachate and substrate EC. Species did not affect leachate EC; therefore, data were pooled across species. The leachate ECs were much higher than that of irrigation water in both control and salinity treatments over the entire experiment. The leachate EC of control solution (nutrient solution at EC of $1.2 \mathrm{dS} \cdot \mathrm{m}^{-1}$ ) ranged from 2.1 to $4.6 \mathrm{dS} \cdot \mathrm{m}^{-1}$ (Fig. 1). For EC 5 and EC 10, the leachate EC increased from 6.0 to $12.7 \mathrm{dS} \cdot \mathrm{m}^{-1}$ and from 8.3 to $18.2 \mathrm{dS} \cdot \mathrm{m}^{-1}$, respectively. The ECs of substrate saturation extract in control or saline solution treatments was similar among different species. The ECs were $1.0 \pm 0.2$,

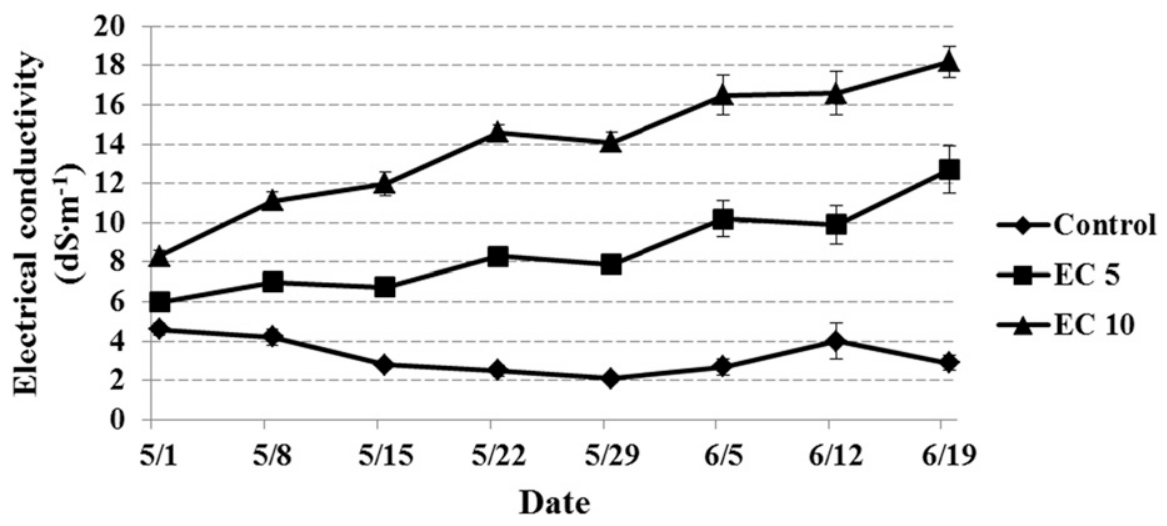

Fig. 1. Variation of weekly leachate electrical conductivity (EC) during the experimental period. The measurement was taken after each treatment solution was applied. Control represents nutrient solution at EC of $1.2 \mathrm{dS} \cdot \mathrm{m}^{-1}$; EC 5 and EC 10 represent the salinity level of the irrigation water at EC of $5.0 \mathrm{dS} \cdot \mathrm{m}^{-1}$ and $10.0 \mathrm{dS} \cdot \mathrm{m}^{-1}$, respectively. The saline solution was applied once a week, and nutrient solution was applied between the treatments. Data were pooled across all species since species did not affect leachate EC. Vertical bars represent standard errors. 
$3.6 \pm 0.3$, and $5.3 \pm 0.4 \mathrm{dS} \cdot \mathrm{m}^{-1}$ in control, EC 5, and EC 10, respectively, regardless of species. The substrate EC increased over time as the salinity of irrigation water increased, indicating that more salts were accumulated in the rhizosphere.

Survival percent, visual quality, and number of inflorescences. All plants survived in EC 5 except butterfly blue and eastern red columbine plants whose survival rates were $80 \%$ (Table 1). All plants of mexican hummingbird bush, rock rose, flame acanthus, and orange peel jessamine were still alive in EC 10 at the end of the experiment, whereas all eastern red columbine plants died. The survival percentage of butterfly blue, cardinal flower, mexican false heather, and 'Dark knight' bluebeard plants in EC 10 ranged from $60 \%$ to $90 \%$.

Salinity of irrigation water in EC 5 and EC 10 did not influence visual quality in mexican hummingbird bush and orange peel jessamine plants. Visual scores of mexican false heather, rock rose, flame acanthus, and 'Dark knight' bluebeard plants in EC 5 were similar to those in control with minimal or no foliar damage in EC 5. In EC 10, rock rose, 'Dark knight' bluebeard, and flame acanthus plants had slight foliar damage, whereas mexican false heather plants experienced severe foliar damage. Butterfly blue plants in control had similar visual quality to those in EC 5, but were much better looking compared with those in EC 10. Cardinal flower and eastern red columbine plants had severe foliage salt damage with leaf burn and necrosis in both EC 5 and EC 10 (Table 1).

As salinity levels increased, number of inflorescences of all species decreased except flame acanthus and orange peel jessamine. Orange peel jessamine plants had similar number of inflorescences between control and salinity treatments, whereas number of inflorescences in flame acanthus plants doubled in EC 10 (Table 1).

Growth parameters. Salinity adversely affected the height/growth index of all the species with rock rose as an exception (Table 2). Growth index of butterfly blue, cardi- nal flower, and eastern red columbine, and height of 'Dark knight' bluebeard plants in EC 5 decreased by more than $20 \%$ compared with their respective controls. In EC 10, butterfly blue, cardinal flower, and eastern red columbine plants had the greatest reductions in growth index (51\% to $75 \%)$, whereas mexican false heather and mexican hummingbird bush plants had the least reduction $(\approx 20 \%)$ in height. Plant heights of flame acanthus, orange peel jessamine, and 'Dark knight' bluebeard plants decreased by $27 \%, 28 \%$, and $40 \%$, respectively. Leaf area and DW of all plants, regardless of species, were reduced by increased salinity levels. Cardinal flower, mexican false heather, and flame acanthus plants in EC 10 had the greatest reduction in leaf area $(>78 \%)$ and DW $(>63 \%)$ than any other species.

Gas exchange, SPAD readings, and chlorophyll fluorescence. Compared with control, EC 5 did not impact $\mathrm{P}_{\mathrm{n}}$ in any species nor did it impact $E$ in any species except eastern red columbine (Table 3 ). Transpiration rate of red columbine decreased by $23 \%$ at EC 5. EC 5 did not impact the $g_{\text {s }}$ in any species with the exception of eastern red columbine and orange peel jessamine. EC 10 decreased $\mathrm{P}_{\mathrm{n}}$ in butterfly blue, cardinal flower, 'Dark knight' bluebeard, and flame acanthus plants by $30 \%$ to $60 \%$ compared with their respective controls. EC 10 only adversely impacted E in butterfly blue and 'Dark knight' bluebeard plants. Compared with control, $g_{\mathrm{s}}$ in butterfly blue, cardinal flower, 'Dark knight' bluebeard, and orange peel jessamine plants decreased in EC 10 with the greatest reduction $(76 \%)$ in 'Dark knight' bluebeard.

All butterfly blue, mexican hummingbird bush, and orange peel jessamine plants had similar SPAD readings, indicating that increased salinity did not affect their relative chlorophyll content (Table 3 ). SPAD readings of cardinal flower plants in EC 5 and EC 10 , and eastern red columbine, 'Dark knight' bluebeard, and flame acanthus plants in EC 10 were lower than the control. There was no difference in SPAD readings in rock rose plants between control and EC 5, whereas
SPAD readings of rock rose plants in EC 10 were greater than the control.

Salinity did not impact chlorophyll fluorescence of the nine species (data not shown), indicating that neither PSII efficiency nor photosynthetic apparatus were affected by salinity.

Mineral analysis. Compared with control, shoot $\mathrm{Na}$ concentration of butterfly blue, mexican hummingbird bush, and orange peel jessamine plants increased by 26,6 , and 3 times in EC 5 and 57, 10, and 5 times, in EC 10 , respectively (Table 4). Shoot Na concentrations of cardinal flower, eastern red columbine, mexican false heather, rock rose, and 'Dark knight' bluebeard, and flame acanthus plants in EC 5 were similar to that of the control, but in EC 10 increased by 150, 70, $71,24,10$, and 2 times, respectively. Mexican hummingbird bush and orange peel jessamine plants had relatively smaller increase in $\mathrm{Na}$ concentration in EC 10 than the other species except for flame acanthus. In addition, correlation analysis was conducted, and a significant correlation between $\mathrm{Na}$ concentration and visual score was obtained $(P<0.0001$, $r=-0.46$ )

The shoot $\mathrm{Cl}$ concentration of mexican false heather plants in EC 10 was 5 to 20 times higher than that of control and EC 5, whereas no difference was found between control and EC 5 (Table 4). Both EC 5 and EC 10 significantly increased the shoot $\mathrm{Cl}$ concentration of the other species. Eastern red columbine plants had the highest increase in the shoot $\mathrm{Cl}$ concentration, with 34 and 61 times more $\mathrm{Cl}$ concentration in EC 5 and EC 10, respectively, than the control. The shoot $\mathrm{Cl}$ concentration of butterfly blue, cardinal flower, mexican hummingbird bush, rock rose, 'Dark knight' bluebeard, flame acanthus, and orange peel jessamine plants increased by 3 to 11 times in EC 5 and 6 to 22 times in EC 10. In addition, there was a significant correlation between $\mathrm{Cl}$ concentration and visual score $(P<0.0001$, $r=-0.76$ )

Salinity did not affect the shoot $\mathrm{K}$ concentration of eastern red columbine, rock

Table 1. Survival rate, visual score, and number of inflorescences of nine species of ornamental plants irrigated with nutrient solution [electrical conductivity $(E C)=1.2 \mathrm{dS} \cdot \mathrm{m}^{-1} ;$ control $]$ or saline solution $\left[E C=5.0 \mathrm{dS} \cdot \mathrm{m}^{-1}(E C 5)\right.$ or $\left.10.0 \mathrm{dS} \cdot \mathrm{m}^{-1}(E C 10)\right]$ in the greenhouse $(\mathrm{n}=10)$. Treatment solutions were applied weekly from 1 May to 19 June (eight times in total), and nutrient solution was applied between the treatments.

\begin{tabular}{|c|c|c|c|c|c|c|c|c|c|}
\hline \multirow[b]{2}{*}{ Species $^{z}$} & \multicolumn{3}{|c|}{ Survival rate $(\%)$} & \multicolumn{3}{|c|}{ Visual score ${ }^{y}$} & \multicolumn{3}{|c|}{ Number of inflorescences } \\
\hline & $\overline{\text { Control }}$ & EC 5 & EC 10 & $\overline{\text { Control }}$ & EC 5 & EC 10 & Control & EC 5 & EC 10 \\
\hline Cardinal flower & 100 & 100 & 70 & $4.7 \mathrm{a}$ & $3.4 \mathrm{~b}$ & $1.5 \mathrm{c}$ & $\mathrm{C}^{\mathrm{w}}$ & - & - \\
\hline Eastern red columbine & 100 & 80 & 0 & $4.6 \mathrm{a}$ & $2.5 \mathrm{~b}$ & $0.1 \mathrm{c}$ & $\mathrm{C}^{\mathrm{w}}$ & - & - \\
\hline Mexican hummingbird bush & 100 & 100 & 100 & $5.0 \mathrm{a}$ & $5.0 \mathrm{a}$ & $5.0 \mathrm{a}$ & $74 \mathrm{a}$ & $47 \mathrm{~b}$ & $33 \mathrm{~b}$ \\
\hline Rock rose & 100 & 100 & 100 & $4.4 \mathrm{a}$ & $4.1 \mathrm{a}$ & $3.2 \mathrm{~b}$ & $126 \mathrm{a}$ & $73 \mathrm{~b}$ & $58 \mathrm{~b}$ \\
\hline 'Dark knight' bluebeard & 100 & 100 & 90 & $5.0 \mathrm{a}$ & $4.8 \mathrm{a}$ & $3.1 \mathrm{~b}$ & $114 \mathrm{a}$ & $100 \mathrm{ab}$ & $20 \mathrm{~b}$ \\
\hline
\end{tabular}

zButterfly blue: Scabiosa columbaria 'Butterfly Blue'; cardinal flower: Lobelia cardinalis; eastern red columbine: Aquilegia canadensis; mexican false heather: Cuphea hyssopifolia; mexican hummingbird bush: Dicliptera suberecta; rock rose: Pavonia lasiopetala; 'Dark knight' bluebeard: Caryopteris $\times$ clandonensis 'Dark Knight'; flame acanthus: Anisacanthus quadrifidus var. wrightii; orange peel jessamine: Cestrum 'Orange Peel'.

${ }^{\mathrm{y}}$ Visual score: $0=$ dead; $1=$ over $90 \%$ foliar damage; $2=$ moderate $(50 \%$ to $90 \%)$ foliar damage; $3=$ slight (less than $\left.50 \%\right)$ foliar damage; $4=$ good quality with minimal foliar damage; and $5=$ excellent with no foliar damage.

${ }^{x}$ Means with same letters within a row are not significantly different among treatments by Tukey’s honest significant difference multiple comparison at $P<0.05$. ${ }^{\mathrm{w}}$ Cardinal flower and eastern red columbine did not bloom during the experiment. 
Table 2. Height/growth index, leaf area, and shoot dry weight (DW) of nine species of ornamental plants irrigated with nutrient solution [electrical conductivity $(E C)=1.2 \mathrm{dS} \cdot \mathrm{m}^{-1}$; control $]$ or saline solution $\left[\mathrm{EC}=5.0 \mathrm{dS} \cdot \mathrm{m}^{-1}(\mathrm{EC} 5)\right.$ or $\left.10.0 \mathrm{dS} \cdot \mathrm{m}^{-1}(\mathrm{EC} 10)\right]$ in the greenhouse $(\mathrm{n}=10)$. Treatment solutions were applied weekly from 1 May to 19 June (eight times in total), and nutrient solution was applied between the treatments.

\begin{tabular}{|c|c|c|c|c|c|c|c|c|c|}
\hline \multirow[b]{2}{*}{ Species $^{2}$} & \multicolumn{3}{|c|}{ Ht/growth index ${ }^{y}(\mathrm{~cm})$} & \multicolumn{3}{|c|}{ Leaf area $\left(\mathrm{cm}^{2}\right)$} & \multicolumn{3}{|c|}{ Shoot DW (g) } \\
\hline & Control & EC 5 & EC10 & Control & EC 5 & EC 10 & Control & EC 5 & EC 10 \\
\hline Cardinal flower & $25.5 \mathrm{a}$ & $17.8 \mathrm{~b}$ & $9.6 \mathrm{c}$ & $1,370.2 \mathrm{a}$ & $479.9 \mathrm{~b}$ & $60.8 \mathrm{c}$ & $13.7 \mathrm{a}$ & $6.4 \mathrm{~b}$ & $4.1 \mathrm{~b}$ \\
\hline Mexican hummingbird bush & $69.8 \mathrm{a}$ & $64.5 \mathrm{ab}$ & $57.7 \mathrm{~b}$ & $1,978.6 \mathrm{a}$ & $1,382.0 \mathrm{~b}$ & $938.9 \mathrm{~b}$ & $43.9 \mathrm{a}$ & $33.2 \mathrm{~b}$ & $24.8 \mathrm{c}$ \\
\hline Rock rose & $84.8 \mathrm{a}$ & $80.8 \mathrm{a}$ & $77.5 \mathrm{a}$ & $1,115.9 \mathrm{a}$ & $626.5 \mathrm{~b}$ & $354.8 \mathrm{~b}$ & $22.0 \mathrm{a}$ & $12.3 \mathrm{~b}$ & $9.1 \mathrm{~b}$ \\
\hline 'Dark knight' bluebeard & $53.4 \mathrm{a}$ & $41.7 \mathrm{~b}$ & $32.2 \mathrm{c}$ & $610.0 \mathrm{a}$ & $473.1 \mathrm{a}$ & $223.7 \mathrm{~b}$ & $15.8 \mathrm{a}$ & $12.6 \mathrm{a}$ & $8.6 \mathrm{~b}$ \\
\hline
\end{tabular}

${ }^{2}$ Butterfly blue: Scabiosa columbaria 'Butterfly Blue'; cardinal flower: Lobelia cardinalis; eastern red columbine: Aquilegia canadensis; mexican false heather: Cuphea hyssopifolia; mexican hummingbird bush: Dicliptera suberecta; rock rose: Pavonia lasiopetala; 'Dark knight' bluebeard: Caryopteris $\times$ clandonensis 'Dark Knight'; flame acanthus: Anisacanthus quadrifidus var. wrightii; orange peel jessamine: Cestrum 'Orange Peel'.

${ }^{y}$ Growth index is used instead of height for butterfly blue, cardinal flower, and eastern red columbine. Growth index is average of height and two crown diameters at perpendicular directions.

${ }^{x}$ Means with same letters within a row are not significantly different among treatments by Tukey's honest significant difference multiple comparison or between treatments by Student's $t$ test $P<0.05$.

"Data were not collected due to plant death.

Table 3. Leaf net photosynthesis $\left(\mathrm{P}_{\mathrm{n}}\right)$, transpiration $(\mathrm{E})$, stomatal conductance $\left(g_{\mathrm{s}}\right)$, and relative chlorophyll content (SPAD) of eight species of ornamental plants irrigated with nutrient solution [electrical conductivity $(E C)=1.2 \mathrm{dS} \cdot \mathrm{m}^{-1} ;$ control] or saline solution $\left[\mathrm{EC}=5.0 \mathrm{dS} \cdot \mathrm{m}^{-1}(\mathrm{EC} 5)\right.$ or $\left.10.0 \mathrm{dS} \cdot \mathrm{m}^{-1}(\mathrm{EC} 10)\right]$ in the greenhouse $(\mathrm{n}=10)$. Treatment solutions were applied weekly from 1 May to 19 June (eight times in total), and nutrient solution was applied between the treatments. All data were measured at the end of the experiment (on 18 June). Mexican false heather was not analyzed because of its small leaves.

\begin{tabular}{|c|c|c|c|c|c|c|c|c|c|c|c|c|}
\hline \multirow[b]{2}{*}{ Species $^{2}$} & \multicolumn{3}{|c|}{$P_{n}\left(\mu \mathrm{mol} \cdot \mathrm{m}^{-2} \cdot \mathrm{s}^{-1}\right)$} & \multicolumn{3}{|c|}{$\mathrm{E}\left(\mathrm{mmol} \cdot \mathrm{m}^{-2} \cdot \mathrm{s}^{-1}\right)$} & \multicolumn{3}{|c|}{$g_{\mathrm{s}}\left(\mathrm{mmol} \cdot \mathrm{m}^{-2} \cdot \mathrm{s}^{-1}\right)$} & \multicolumn{3}{|c|}{ SPAD } \\
\hline & $\overline{\text { Control }}$ & EC 5 & EC 10 & Control & EC 5 & $\overline{E C ~} 10$ & Control & EC 5 & EC 10 & Control & EC 5 & EC 10 \\
\hline Cardinal flower & $9.3 \mathrm{a}$ & $7.6 \mathrm{ab}$ & $4.2 \mathrm{~b}$ & $5.2 \mathrm{a}$ & $4.5 \mathrm{a}$ & $3.6 \mathrm{a}$ & $285.0 \mathrm{a}$ & $266.0 \mathrm{ab}$ & $173.0 \mathrm{~b}$ & $52.9 \mathrm{a}$ & $41.5 \mathrm{~b}$ & $39.2 \mathrm{~b}$ \\
\hline Roc & $13.6 \mathrm{a}$ & $14.4 \mathrm{a}$ & $12.5 \mathrm{a}$ & $7.7 \mathrm{a}$ & $7.0 \mathrm{a}$ & $5.7 \mathrm{a}$ & $0.0 \mathrm{a}$ & $468.2 \mathrm{a}$ & $348.5 \mathrm{a}$ & $62.8 \mathrm{~b}$ & $64.0 \mathrm{~b}$ & $8.2 \mathrm{a}$ \\
\hline 'Dark knight' bluebeard & $19.9 \mathrm{a}$ & $16.7 \mathrm{a}$ & $7.9 \mathrm{~b}$ & $8.8 \mathrm{a}$ & $8.7 \mathrm{a}$ & $4.0 \mathrm{~b}$ & $593.4 \mathrm{a}$ & $567.3 \mathrm{a}$ & $145.6 \mathrm{~b}$ & $40.0 \mathrm{a}$ & $40.1 \mathrm{a}$ & $9.5 \mathrm{~b}$ \\
\hline Flame acanthus & $9.9 \mathrm{a}$ & $7.4 \mathrm{ab}$ & $4.5 \mathrm{~b}$ & $4.8 \mathrm{a}$ & $3.3 \mathrm{a}$ & $4.0 \mathrm{a}$ & $130.0 \mathrm{a}$ & $120.5 \mathrm{a}$ & $110.3 \mathrm{a}$ & $44.5 \mathrm{a}$ & $39.3 \mathrm{ab}$ & $36.6 \mathrm{~b}$ \\
\hline
\end{tabular}

${ }^{2}$ Butterfly blue: Scabiosa columbaria 'Butterfly Blue'; cardinal flower: Lobelia cardinalis; eastern red columbine: Aquilegia canadensis; mexican hummingbird bush: Dicliptera suberecta; rock rose: Pavonia lasiopetala; 'Dark knight' bluebeard: Caryopteris $\times$ clandonensis 'Dark Knight'; flame acanthus: Anisacanthus quadrifidus var. wrightii; orange peel jessamine: Cestrum 'Orange Peel'.

${ }^{y}$ Means with same letters within a row are not significantly different among treatments by Tukey's honest significant difference multiple comparison or between treatments by Student's $t$ test $P<0.05$.

${ }^{x}$ Data were not collected due to plant death.

rose, and flame acanthus plants (Table 4). Compared with control, EC 10 increased the shoot $\mathrm{K}$ concentration of mexican false heather plants by $20 \%$, whereas it decreased that in the other five species by $13 \%$ to $32 \%$. In addition, EC 5 also decreased the shoot $\mathrm{K}$ concentration of butterfly blue, 'Dark knight' bluebeard, and orange peel jessamine plants by $14 \%, 22 \%$, and $19 \%$, respectively. The relationship between $\mathrm{K}$ concentration and visual score was not significant $(P=0.84)$.

The effect of salinity on shoot $\mathrm{Ca}$ concentration varied with plant species (Table 4). Salinity did not impact the shoot Ca concentration of flame acanthus plants, whereas it increased the shoot $\mathrm{Ca}$ concentration of the remaining eight species. The shoot $\mathrm{Ca}$ concentration of cardinal flower, mexican false heather, rock rose, and 'Dark knight' bluebeard plants in EC 5 was similar to that of the control, but in EC 10 was $72 \%, 288 \%, 57 \%$, $94 \%$, respectively, higher than that of the control. Compared with the control, the shoot Ca concentration of butterfly blue, eastern red columbine, and orange peel jessamine plants in EC 5 increased by $86 \%, 66 \%$, and $57 \%$, and in EC 10 by $116 \%, 173 \%$, and $107 \%$, respectively. The shoot $\mathrm{Ca}$ concentration of mexican hummingbird bush plants in EC 5 and $\mathrm{EC} 10$ was $78 \%$ higher than that in the control. Ca concentration also had a significant correlation with visual score $(P=0.0009$, $r=-0.32$ ).

Interestingly, it should be noted that many salt crystals formed on the surface of leaves in rock rose when they were irrigated with saline solution treatments.

\section{Discussion}

Plant response to salinity. Salt-tolerant plants usually have less growth reduction and less foliar salt injury at elevated salinity (Cassaniti et al., 2009; Niu and Rodriguez, 2006a). Foliar salt damage, such as tip burn, leaf-margin burn, necrosis, and discoloration has, been evaluated visually to determine the salt tolerance of ornamental plants (Cai et al., 2014a, 2014b; Niu and Rodriguez, 2006a, 2006b; Niu et al., 2012a, 2012b; Zollinger et al., 2007). Mexican hummingbird bush and orange peel jessamine did not have any visual salt damage even in EC 10 and had less reduction in shoot DW than the other species tested, thus they are considered highly salt tolerant. Rock rose, flame acanthus, and 'Dark knight' bluebeard plants had little foliar salt damage and $20 \%$ to $40 \%$ reduction in shoot DW in EC 5, and thus they are considered as moderately salt-tolerant species. The remaining four species investigated are considered as salt-sensitive species because they had slight (less than 50\%) foliar damage in EC 5 and over $50 \%$ of foliar damage with $49 \%$ to $80 \%$ reduction in shoot DW in EC 10.

Salinity effect flower (inflorescence) characteristics of ornamental plants. Salinity reduced the number of flowers of rock samphire (Crithmum maritimum) (Ventura et al., 2014), garden roses (Rosa hybrida) (Niu et al., 2013), and chamomile (Matricaria chamomila) (Razmjoo et al., 2008). In the current study, the number of inflorescences of butterfly blue, mexican false heather, mexican hummingbird bush, rock rose, and 'Dark knight' bluebeard plants was also reduced as salinity of irrigation solution increased. However, the number of inflorescences of orange peel jessamine plants was unaffected by salinity. Interestingly, the number of inflorescences of flame acanthus plants was doubled in 
Table 4. Shoot $\mathrm{Na}, \mathrm{Cl}, \mathrm{K}$, and Ca concentrations measured at the end of the experiment. Nine ornamental species were irrigated with nutrient solution [electrical conductivity $(\mathrm{EC})=1.2 \mathrm{dS} \cdot \mathrm{m}^{-1}$; control] or saline solution $\left[\mathrm{EC}=5.0 \mathrm{dS} \cdot \mathrm{m}^{-1}(\mathrm{EC} 5)\right.$ or $\left.10.0 \mathrm{dS} \cdot \mathrm{m}^{-1}(\mathrm{EC} 10)\right]$ in the greenhouse $(\mathrm{n}=10)$. Treatment solutions were applied weekly from 1 May to 19 June (eight times in total), and nutrient solution was applied between the treatments.

\begin{tabular}{|c|c|c|c|c|c|}
\hline \multirow[b]{2}{*}{ Species $^{\mathrm{z}}$} & \multirow[b]{2}{*}{ Treatment } & \multicolumn{4}{|c|}{ Ion concn $\left(\mathrm{mg} \cdot \mathrm{g}^{-1}\right)$} \\
\hline & & $\mathrm{Na}$ & $\mathrm{Cl}$ & $\mathrm{K}$ & $\mathrm{Ca}$ \\
\hline \multirow[t]{3}{*}{ Butterfly blue } & Control & $0.2 \mathrm{c}^{\mathrm{y}}$ & $2.7 \mathrm{c}$ & $35.8 \mathrm{a}$ & $8.3 \mathrm{c}$ \\
\hline & EC 5 & $4.0 \mathrm{~b}$ & $31.1 \mathrm{~b}$ & $30.9 \mathrm{~b}$ & $15.5 \mathrm{~b}$ \\
\hline & EC 10 & $8.8 \mathrm{a}$ & $51.9 \mathrm{a}$ & $31.0 \mathrm{~b}$ & $18.0 \mathrm{a}$ \\
\hline \multirow[t]{3}{*}{ Cardinal flower } & Control & $0.1 \mathrm{~b}$ & $10.3 \mathrm{c}$ & $39.5 \mathrm{a}$ & $9.2 \mathrm{~b}$ \\
\hline & EC 5 & $2.9 \mathrm{~b}$ & $50.7 \mathrm{~b}$ & $33.5 \mathrm{ab}$ & $15.7 \mathrm{~b}$ \\
\hline & EC 10 & $18.8 \mathrm{a}$ & $102.6 \mathrm{a}$ & $26.7 \mathrm{~b}$ & $38.5 \mathrm{a}$ \\
\hline \multirow[t]{3}{*}{ Eastern red columbine } & Control & $0.1 \mathrm{~b}$ & $1.2 \mathrm{c}$ & $34.8 \mathrm{a}$ & $9.7 \mathrm{c}$ \\
\hline & EC 5 & $0.7 \mathrm{~b}$ & $43.3 \mathrm{~b}$ & $31.8 \mathrm{a}$ & $16 \mathrm{~b}$ \\
\hline & EC 10 & $7.1 \mathrm{a}$ & $75.8 \mathrm{a}$ & $35.7 \mathrm{a}$ & $26.3 \mathrm{a}$ \\
\hline \multirow[t]{3}{*}{ Mexican false heather } & Control & $0.3 \mathrm{~b}$ & $3.6 \mathrm{~b}$ & $15.3 \mathrm{~b}$ & $7.1 \mathrm{~b}$ \\
\hline & EC 5 & $2.4 \mathrm{~b}$ & $12.7 \mathrm{~b}$ & $14.0 \mathrm{~b}$ & $10.1 \mathrm{~b}$ \\
\hline & EC 10 & $17.9 \mathrm{a}$ & $73.2 \mathrm{a}$ & $18.5 \mathrm{a}$ & $27.5 \mathrm{a}$ \\
\hline \multirow[t]{3}{*}{ Mexican hummingbird bush } & Control & $1.5 \mathrm{c}$ & $2.3 \mathrm{c}$ & $29.2 \mathrm{a}$ & $23.9 \mathrm{~b}$ \\
\hline & EC 5 & $10.4 \mathrm{~b}$ & $23.9 \mathrm{~b}$ & $29.3 \mathrm{a}$ & $42.5 \mathrm{a}$ \\
\hline & EC 10 & $15.7 \mathrm{a}$ & $40.6 \mathrm{a}$ & $25.0 \mathrm{~b}$ & $42.5 \mathrm{a}$ \\
\hline \multirow[t]{3}{*}{ Rock rose } & Control & $0.1 \mathrm{~b}$ & $1.9 \mathrm{c}$ & $30.5 \mathrm{a}$ & $20.6 \mathrm{~b}$ \\
\hline & EC 5 & $0.7 \mathrm{~b}$ & $16.1 \mathrm{~b}$ & $29.4 \mathrm{a}$ & $25.4 \mathrm{ab}$ \\
\hline & EC 10 & $3.1 \mathrm{a}$ & $43.1 \mathrm{a}$ & $26.7 \mathrm{a}$ & $32.4 \mathrm{a}$ \\
\hline \multirow[t]{3}{*}{ 'Dark knight' bluebeard } & Control & $0.3 \mathrm{~b}$ & $1.5 \mathrm{c}$ & $22.9 \mathrm{a}$ & $7.4 \mathrm{~b}$ \\
\hline & EC 5 & $0.4 \mathrm{~b}$ & $12.7 \mathrm{~b}$ & $17.9 \mathrm{~b}$ & $13.3 \mathrm{ab}$ \\
\hline & EC 10 & $3.3 \mathrm{a}$ & $27.0 \mathrm{a}$ & $17.8 \mathrm{~b}$ & $14.4 \mathrm{a}$ \\
\hline \multirow[t]{3}{*}{ Flame acanthus } & Control & $0.2 \mathrm{~b}$ & $3.4 \mathrm{c}$ & $27.5 \mathrm{a}$ & $30.6 \mathrm{a}$ \\
\hline & EC 5 & $0.3 \mathrm{~b}$ & $19.7 \mathrm{~b}$ & $25.4 \mathrm{a}$ & $33.0 \mathrm{a}$ \\
\hline & EC 10 & $0.7 \mathrm{a}$ & $24.2 \mathrm{a}$ & $26.1 \mathrm{a}$ & $28.5 \mathrm{a}$ \\
\hline \multirow[t]{3}{*}{ Orange peel jessamine } & Control & $1.0 \mathrm{c}$ & $7.0 \mathrm{c}$ & $37.6 \mathrm{a}$ & $11.2 \mathrm{c}$ \\
\hline & EC 5 & $3.3 \mathrm{~b}$ & $24.5 \mathrm{~b}$ & $30.5 \mathrm{~b}$ & $17.6 \mathrm{~b}$ \\
\hline & EC 10 & $6.1 \mathrm{a}$ & $45.7 \mathrm{a}$ & $25.8 \mathrm{c}$ & $23.2 \mathrm{a}$ \\
\hline
\end{tabular}

zButterfly blue: Scabiosa columbaria 'Butterfly Blue'; cardinal flower: Lobelia cardinalis; eastern red columbine: Aquilegia canadensis; mexican false heather: Cuphea hyssopifolia; mexican hummingbird bush: Dicliptera suberecta; rock rose: Pavonia lasiopetala; 'Dark knight' bluebeard: Caryopteris $\times$ clandonensis 'Dark Knight'; flame acanthus: Anisacanthus quadrifidus var. wrightii; orange peel jessamine: Cestrum 'Orange Peel'.

${ }^{y}$ Means with same letters within a column for each species are not significantly different among treatments by Tukey’s honest significant difference multiple comparison at $P<0.05$.

EC 10 compared with that of the control. Shillo et al. (2002) also reported that a salinity level of $6.0 \mathrm{dS} \cdot \mathrm{m}^{-1}$ increased the number of flowers of lisianthus (Eustoma grandiflorum).

The effect of salinity on gas exchange is dependent on plant species and/or cultivars. It is also affected by many other factors such as the level of salinity and duration of exposure to salt stress (Niu and Cabrera, 2010). In this study, mexican hummingbird bush, rock rose, and orange peel jessamine plants had similar $P_{n}$ across salinity treatments, whereas butterfly blue, cardinal flower, 'Dark knight' bluebeard, and flame acanthus plants in EC 10 had lower $P_{n}$ than that of the control. All plant species tested in the study also had similar E across salinity treatments, with the exception of butterfly blue, eastern red columbine, and 'Dark knight' bluebeard plants where E was significantly reduced by salinity at EC 10. In addition, the $g_{\mathrm{s}}$ of butterfly blue, cardinal flower, eastern red columbine, 'Dark knight' bluebeard, and orange peel jessamine plants were decreased significantly at EC 10. In our previous reports, Texas Superstar ${ }^{\circledR}$ perennials also had different responses of $P_{n}$ to elevated salinity (Sun et al., 2015).

SPAD readings, which are relative chlorophyll contents, have been used as a reference index for evaluating the salt tolerance of plants (Niu and Cabrera, 2010). SPAD readings were reduced with increasing salinity stress for Gaillardia aristata (Niu et al.,
2007). However, the relationship between SPAD readings and the salt tolerance of plants is inconsistent in previous research reports (Niu et al., 2007, 2012b). In this study, salinity increased SPAD readings in rock rose plants, but decreased SPAD readings in cardinal flower, eastern red columbine, flame acanthus, and 'Dark knight' bluebeard plants. In addition, salinity had no impact on SPAD readings in butterfly blue, mexican hummingbird bush, and orange peel jessamine plants.

Although chlorophyll fluorescence has been offered as a potentially quick, reliable, and inexpensive procedure to detect the variation of ornamental plants in response to salinity (Percival, 2005), in this study, salinity did not impact the chlorophyll fluorescence of the nine plant species. In our previous study, the chlorophyll fluorescence of 10 aster species (Wu et al., 2016) also had no difference among treatments.

Mechanisms of salt tolerance. Plants adapt to salinity through tolerance of accumulated $\mathrm{Na}$ or $\mathrm{Cl}$ in plant tissue, $\mathrm{Na}$ or $\mathrm{Cl}$ exclusion, and osmotic adjustment (Munns and Tester, 2008). In this study, mexican hummingbird bush and orange peel jessamine plants had high concentrations of $\mathrm{Na}$, $\mathrm{Ca}$, and $\mathrm{Cl}$ ions in shoots at both salinity levels, while no visual foliar damage was observed. These results indicate that mexican hummingbird bush and orange peel jessamine plants tolerated high accumulation of
$\mathrm{Na}$ and $\mathrm{Cl}$ ions in the tissue. Butterfly blue, cardinal flower, eastern red columbine, and mexican false heather plants also had relatively high shoot $\mathrm{Na}$ and $\mathrm{Cl}$ concentrations, but they exhibited severe foliar salt damage, which indicated low tolerance of $\mathrm{Na}$ and $\mathrm{Cl}$ accumulation and low ability to exclude these ions from shoots.

Rock rose, 'Dark knight' bluebeard, and flame acanthus plants had relatively low shoot $\mathrm{Na}$ concentration at EC 10 and $\mathrm{Cl}$ concentration at both EC 5 and EC 10 with acceptable visual quality. This might suggest that they have the ability to restrict $\mathrm{Na}$ and/or $\mathrm{Cl}$ uptake and transport to shoots (Niu et al., 2013). In addition, rock rose plants may have the capability to exude the excess toxic salts via secretory structures like salt glands and microhairs, which were observed in leaves. This phenomenon was also observed in turk's cap (Malvaviscus arboreus var. drummondii) (Sun et al., 2015), blue plumbago (Plumbago auriculata 'Escapade Blue') (Niu et al., 2010), salt cedar (Tamarix sp.) (Bell et al., 2010), and salt bush (Atriplex sp.) (Hameed et al., 2010). These species developed specialized salt glands and microhairs on the surface of leaves, through which excess toxic ions are secreted and form salt crystals on leaf surface to reduce the harmfulness to plants (Taiz and Zeiger, 2015).

Potassium is one of the important mineral nutrient elements in the turgor pressure-driven 
solute transport in the xylem and the water balance of plants (Marschner, 1995). Plants exposed to $\mathrm{NaCl}$ inevitably accumulate a great amount of $\mathrm{Na}$, which usually causes a reduction in $\mathrm{K}$ contents (Hasegawa et al., 2000). In our study, as the salinity level of the irrigation water increased, the shoot $\mathrm{K}$ concentration of butterfly blue, cardinal flower, mexican hummingbird bush, 'Dark knight' bluebeard, and orange peel jessamine plants decreased significantly. This information suggests that these plants may also use osmotic adjustment to lower water potential of their tissue. In addition, $\mathrm{K}$ may transport against a strong $\mathrm{Na}$ concentration gradient (Grattan and Grieve, 1999). In this study, leaf $\mathrm{K}$ concentration increased significantly with increasing EC in mexican false heather plants. Sun et al. (2015) also observed that K level increased significantly with increasing EC in the leaves of 'John Fanick' phlox (Phlox paniculata 'John Fanick') and 'Texas Pink' phlox (Phlox paniculata 'Texas Pink') plants. On the other hand, the shoot K concentrations of eastern red columbine, rock rose, and flame acanthus plants were not different among treatments. All these results might suggest that the efficiency of K uptake is species dependent and an adequate $\mathrm{K}$ level is preferentially acquired for plant survival in salt conditions.

In summary, based on the growth and physiological responses of nine ornamental plant species to saline solutions, orange peel jessamine and mexican hummingbird bush were the most salt-tolerant species, and flame acanthus, rock rose, and 'Dark knight' bluebeard were moderately salt-tolerant species. Butterfly blue, mexican false heather, and cardinal flower were moderately salt-sensitive species, whereas eastern red columbine was the most salt sensitive among the species investigated.

\section{Literature Cited}

Bell, C.E., B. Neil, J.M. DiTomaso, W.T. Lanini, J. Lovich, R. DeGouvenain, A. Chavez, T. Egan, C. Deuser, B. Wiesenborn, N. Jackson, and C. Barrows. 2010. Saltcedar, a non-native invasive plant in the western U.S. WRIC Leaflet \#02-2. WEED Research \& Information Center, University of California, Davis, CA.

Cai, X., G. Niu, T. Starman, and C. Hall. 2014a. Response of six garden roses (Rosa $\times$ hybrida L.) to salt stress. Sci. Hort. 168:27-32.
Cai, X., Y. Sun, T. Starman, C. Hall, and G. Niu. 2014b. Response of 18 Earth-Kind ${ }^{\circledR}$ rose cultivars to salt stress. HortScience 49:544-549.

Cassaniti, C., C. Leonardi, and T.J. Flowers. 2009 The effect of sodium chloride on ornamental shrubs. Sci. Hort. 122:586-593.

Cavins, T.J., B.E. Whipker, and W.C. Fonteno. 2008. Pourthru: A method for monitoring nutrition in the greenhouse. Acta Hort. 779:289-297.

Gavlak, R.G., D.A. Horneck, and R.O. Miller. 1994. Plant, soil, and water reference methods for the western region. Western Regional Extension Publication 125.

Grattan, S.R. and C.M. Grieve. 1999. Salinitymineral nutrient relations in horticultural crops. Sci. Hort. 78:127-157.

Hameed, M., M. Ashraf, M. Sajid, A. Ahmad, and N. Naz. 2010. Structural and functional adaptations in plants for salinity tolerance, p. 151170. In: M. Ashraf, M. Ozturk, and M.S.A. Ahmad (eds.). Plant adaptation and phytoremediation. Springer, New York, NY.

Hasegawa, P.M., R.A. Bressan, J.K. Zhu, and H.J. Bohnert. 2000. Plant cellular and molecular responses to salinity. Annu. Rev. Plant Physiol. Plant Mol. Biol. 51:463-499.

Havlin, J.L. and P.N. Soltanpour. 1989. A nitric acid and plant digest method for use with inductively coupled plasma spectrometry. Commun. Soil Sci. Plant Anal. 14:969-980.

Isaac, R.A. and W.C. Johnson. 1975. Collaborative study of wet and dry ashing techniques for the elemental analysis of plant tissue by atomic absorption spectrophotometry. J. Assoc. Off. Anal. Chem. 58:436-440.

Marschner, H. 1995. Mineral Nutrition of Higher Plants. 2nd ed. Academic Press, London, UK.

Munns, R. 2002. Comparative physiology of salt and water stress. Plant Cell Environ. 25:239250 .

Munns, R. and M. Tester. 2008. Mechanisms of salinity tolerance. Annu. Rev. Plant Biol. 59:651-681.

Niu, G. and R.I. Cabrera. 2010. Growth and physiological responses of landscape plants to saline water irrigation: A review. HortScience 45:1605-1609.

Niu, G. and D.S. Rodriguez. 2006a. Relative salt tolerance of selected herbaceous perennials and groundcovers. Sci. Hort. 110:352-358.

Niu, G. and D.S. Rodriguez. 2006b. Relative salt tolerance of five herbaceous perennials. HortScience 41:1493-1497.

Niu, G., D.S. Rodriguez, and L. Aguiniga. 2007. Growth and landscape performance of ten herbaceous species in response to saline water irrigation. J. Environ. Hort. 25(4):204-210.

Niu, G., D.S. Rodriguez, and C. McKenney. 2012a. Response of selected wildflower species to saline water irrigation. HortScience 47:13511355.

Niu, G., D.S. Rodriguez, and T. Starman. 2010. Response of bedding plants to saline water irrigation. HortScience 45:628-636.

Niu, G., T. Starman, and D. Byrne. 2013. Responses of growth and mineral nutrition of garden roses to saline water irrigation. HortScience 48:756-761.

Niu, G., M. Wang, D.S. Rodriguez, and D. Zhang. 2012b. Response of zinnia plants to saline water irrigation. HortScience 47:793-797.

Percival, G.C. 2005. Identification of foliar salt tolerance of woody perennials using chlorophyll fluorescence. HortScience 40:18921897.

Razmjoo, K., P. Heydarizadeh, and M.R. Sabzalian. 2008. Effect of salinity and drought stresses on growth parameters and essential oil content of Matricaria chamomila. Intl. J. Agr. Biol. 10: 451-454.

San Diego County Water Authority. 2015. Greener landscapes for San Diego: Guide for using recycled water. $10 \mathrm{Aug}$. 2015. <http://www.sdcwa. $\mathrm{org} / \mathrm{sites} / \mathrm{default} /$ files/files/water-management/ recycled/sdcwa-recycled-landscape-guide.pdf $>$.

Shillo, R., M. Ding, D. Pasternak, and M. Zaccai. 2002. Cultivation of cut flower and bulb species with saline water. Sci. Hort. 92: 41-54.

Sun, Y., G. Niu, and C. Perez. 2015. Relative salt tolerance of seven Texas Superstar ${ }^{\circledR}$ perennials. HortScience 50:1562-1566.

Taiz, L. and E. Zeiger. 2015. Plant physiology and development. 6th ed. Sinauer Associates, Inc., Publishers, Sunderland, M.A.

Veatch-Blohm, M.E., D. Sawch, N. Elia, and D. Pinciotti. 2014. Salinity tolerance of three commonly planted Narcissus cultivars. HortScience 49:1158-1164.

Ventura, Y., M. Myrzabayeva, Z. Alikulov, R. Omarov, I. Khozin-Goldberg, and M. Sagi. 2014. Effects of salinity on flowering, morphology, biomass accumulation and leaf metabolites in an edible halophyte. AoB Plants 6: Plu053, doi: 10.1093/aobpla/plu053.

Wu, L. and L. Dodge. 2005. Landscape plant salt tolerance selection guide for recycled water irrigation. $20 \mathrm{Aug}$. 2015.<http://slosson.ucdavis. edu/Landscape_Plant_Selection_Guide_for_ Recycled_Water_Irrigation/ $>$.

Wu, S., Y. Sun, G. Niu, J. Altland, and R.I Cabrera. 2016. Response of ten aster species to saline water irrigation. HortScience 51:197201.

Zollinger, N., R. Koenig, T. Cerny-Koenig, and R. Kjelgren. 2007. Relative salinity tolerance of intermountain western United States native herbaceous perennials. HortScience 42:529534. 